\title{
OPTIMALISASI MANAJEMEN DESAIN PADA MEDIA KOMUNIKASI WEBSITE UNTUK MENINGKATKAN AKTIVITAS BISNIS
}

\author{
Maulid Agung Triono \\ Program Studi Manajemen, FEB, Universitas Merdeka Malang \\ Jl. Terusan Raya Dieng No. 62-64 Malang \\ maulid.agung@unmer.ac.id
}

\begin{abstract}
Website management for all companies or organizations is carried out on an basis, and provides a separate space for optimizing the delivery of information, especially relating to products or services. Currently, information and communication technology has become a starting point for managing operational and managerial activities. This will lead to the acquisition of the latest, fast and accurate information in order to support decision making. Basic capital in the realm of information systems that utilize intelligent devices, is an innovation better known as electronic computers set and the internet. When faced with business activities that legalize information disclosure, it is certainly able to provide opportunities for the growth of the communication business and its development by optimizing information technology. This literature study, seeks to dissect the optimization of design management in website communication media as a medium for business improvement. In order to gain an in-depth understanding, efforts were made to bring together a variety of important studies from the dimensions of communication media and business management, in order be able to discover the interconnectedness of various facts in a comprehensive manner. The results of the study illustrate that improving business communication based on technology by utilizing a website, this is inseparable from the concept of the sustainability of an information quality which two point includes: (1) technology exists to achieve the highest level of efficiency in time, human and cost management that demands an adaptive attitude to market fluctuations; (2) management communication perspective puts opportunity as business control, so that the relationships that have been pursued provide positive values in line with the use of the latest communication technology.
\end{abstract}

Keywords: website, design management, business communication

\begin{abstract}
Abstrak
Pengelolaan website bagi sebuah perusahaan/organisasi dilakukan secara berkelanjutan dan memberikan ruang tersendiri untuk melakukan optimalisasi penyampaian informasi, khususnya yang berkaitan dengan produk/jasa. Saat ini teknologi dan informasi menjadi starting point untuk mengelola kegiatan operasional hingga manajerial perusahaan. Hal ini akan mengarah pada pemerolehan informasi yang cepat dan akurat serta terbaru dan memang dibutuhkan untuk pengambilan sebuah keputusan. Modal dasar pada ranah sistem informasi yang dikomputerisasi merupakan sebuah inovasi yang lebih dikenal dengan computer elektronik dan internet. Ketika dihadapkan dengan aktivitas bisnis yang melegalkan keterbukaan informasi, tentunya mampu memberi peluang bagi tumbuh kembangnya bisnis komunikasi dengan mengoptimalkan teknologi informasi. Artikel ini mencoba membedah
\end{abstract}




\section{JURNAL NOMOSLECA}

Volume 5 Nomor 2, Oktober 2019

optimalisasi manajemen desain pada media komunikasi website sebagai medium bagi peningkatan bisnis. Penggunaan metode studi literatur mempertemukan beberapa kajian penting dari kacamata dunia komunikasi dan ekonomi, dan akan dipertautkan secara lebih komprehensif. Hasil studi literatur memberikan gambaran bahwa peningkatan bisnis komunikasi yang didukung oleh website tidak terlepas dari konsep information quality. Hasil yang lebih dapat dipertotonkan adalah konsep baru tentang manajemen desain yang menekankan pada pertimbangan teknis hingga sosial budaya.

Kata kunci : Website, manajemen desain, komunikasi bisnis

\section{PENDAHULUAN}

\section{Konseptualisasi Manajemen Desain} Pada Aktivitas Bisnis

Aktivitas bisnis saat ini menjadi pokok bahasan serta menjadi sebuah rutinitas yang dekat dengan masyarakat. Kegiatan keseharian tidak haya berfokus pada rutinitas yang sudah tertanam sejak kecil, namun melebarkan sayap untuk memberikan peluang mengembangkan diri untuk terjun dalam bisnis, menjadi pelaku, pengambil kebijakan hingga menjadi orang yang mampu mengelaborasi sebuah aktivitas untuk mendapatkan penghasilan. Jika dilihat kembali tentang aktivits bisnis di masyarakat, maka tidak hanya terbatas pada bisnis yang lebih menekankan pertemuan secara tatap muka langsung, namun juga sudah bisa memanfaatkan perkembangan teknologi yang fantastis, yaitu menggunakan website atau juga mengoptimalkan media sosial yang ada.

Bisa dipastikan bahwa rutinitas dari masyarakat tersebut haruslah ditata sedemikian rupa, sehingga tetap fokus pada tujuan yang ingin dicapai. Terlepas dari tata kelola yang masing-masing memiliki strategi berbeda, adalah manajemen pengelolaan yang profesional menjadi satu kesatuan yang tidak bisa dilepaskan.

Masyarakat mengenal sebuah desain manajemen, merupakan sebuah proses dan berkaitan dengan keputusan bisnis yang ditetapkan serta adanya keberlanjutan dengan menerapkan sebuah inovasi. Keberlanjutan tersebut juga memiliki keterkaitan dengan penciptaan sebuah produk, memunculkan stadart layanan yang bagus serta setiap saat ada perancangan ulang dan tertata. Hal ini pastinya tujuanya adalah menciptakan sebuah kualitas dalam laju sebuah bisnis.

Sedangkan saat ini masyarakat menyadari, ada sebuah kolaborasi yang cukup bagus pada bidang manajemen desain dengan melibatkan perkembangan teknologi informasi. Sejatinya kehadiran sebuah teknologi adalah untuk menjadi pelengkap kehidupan masyarakat, bukan untuk menggantikan posisi aktivitas masyarakat secara fisik. Namun lebih pada munculnya kontribusi untuk menghasilkan 
pola pikir serta perilaku yang lebih terstruktur. Manajemen desain pada aktivitas bisnis yang melibatkan internet misalnya, mampu berfokus pada pengelolaan strategi hingga upaya untuk meningkatkan kualitas aktivitas bisnis.

Aktivitas bisnis yang melibatkan media komunikasi website, memunculkan pemahaman bahwa manajemen desain adalah salah satu tindakan yang mendapatkan sebuah prioritas untuk memilih langkah-langkah praktis dan sebuah langkah antisipasi terhadap permasalahan yang muncul dalam jangka waktu dekat maupun tanpa direncanakan.

Jika manajemen desain berkaitan dengan tujuan strategis bagi perusahaan, maka ada tugas yang diemban oleh pelaku bisnis untuk menentukan manajemen desain yang menjadi andalan atau menjadi prioritas utama. Kebijakan menentukan pola desain ini memiliki keterkaitan kuat dengan adanya sumber daya manusia yang mengelola hal tersebut, baik pada prosesnya maupun langkah praktis untuk membuat suatu inovasi.

Manajemen desain merupakan konsep yang bergerak untuk menghasilkan sebuah karya dengan alat bantu teknologi sehingga dapat memenuhi kebutuhan pasar. Manajemen desain pada media komunikasi website tidak hanya bergerak secara lambat, namun kemampuan mengoptimalkan setiap vitur yang ada serta melakukan terobosan tentunya menjadi sebuah role models yang disukai oleh masyarakat. Kebijakan operasional tidak menjadi penghalang untuk memunculkan kreativitas, namun hal tersebut adalah sebagai motivator serta pengendali bagi laju sebuah bisnis. Manajemen desain itu unik dan menuntut untuk selalu kreatif dan inovatif namun tidak melanggar koridor yang telah ditetapkan di dunia bisnis. Rambu-rambu pada tahapan aplikasi secara normatif menjadi sesuatu yang penting.

\section{Makna Penting Website bagi Peningkatan Komersialisasi Bidang Usaha}

Keistimewaan yang dimiliki masyarakat yang bergerak dalam bisnis dengan memanfaatkan teknologi informasi adalah terbukanya kesempatan yang lebih besar dalam menjangkau masyarakat serta dapat mengenalkan produk/jasa dengan mudah. Masyarakat saat ini menjadi sasaran dari bisnis yang mengusung internet sebagai medium beriklan, sehingga dianggap sebagai kelompok sasaran primer.

Jika dikaji lebih jauh, maka memperlihatkan satu keunggulan dari website ketika mampu mengusung dan membungkus informasi dengan menarik. Tujuannya tidak selalu pada sebuah keputusan pembelian secara langsung, namun lebih pada upaya untuk 
menanamkan kebenak masyarakat tentang sebuah produk/jasa. Dalam jangka waktu tertentu daya ingat masyarakat tertuju pada produk/jasa yang diusung melalui website.

Manajemen bisnis dengan melibatkan website dianggap sebagai sebuah aktivitas untuk mengelola website yang ditujukan untuk meningkatkan efisiensi kerja sehingga memiliki tampilan yang layak. Gaya bahasa penulisan serta tersajinya informasi yang akurat dapat dimanfaatkan secara maksimal oleh user (Triono dkk, 2017:76). Saat ini, kemajuan teknologi atau identik dengan konsep telekomunikasi, diakui memberikan dukungan pada penggunaan internet sebagai medium untuk menyampaikan dan memperoleh informasi, khususnya yang dapat menunjang bisnis.

Penggunaan website sendiri saat ini dalam ranah bisnis akan mengubah fungsi alat pertukaran informasi menjadi medium untuk mendukung aplikasi bisnis, yang identik dengan pemasaran, penjualan serta pelayanan yang harus secara intens menerpa masyarakat. Kesadaran untuk mengoptimalkan website dalam ranah bisnis membawa arti penting bagi terselenggaranya bisnis yang lebih bisa menangkap kemauan bahkan selera masyarakat, karena saat ini selera mayarakat terus berubah sejalan dengan kemudahan dalam memperoleh informasi melalui berbagai media.
Jika dikaji lebih jauh dan komprehensif, memperlihatkan bahwa pengguna internet telah merambah ke berbagai tatanan usia dari yang muda hingga dewasa, bahkan anak-anak saat ini aktivitas keseharian tidak bisa terlepas dari penggunaan medium komunikasi yang terhubung langsung dengan internet. Adanya pertukaran informasi melalui internet, tetap melibatkan individu atau kelompok yang memiliki tanggungjawab untuk mengirimkan pesan dan menyebarkan secara massif.

Makna penting dari keputusan menggunakan website sebagai medium yang mengusung sebuah bisnis adalah hal yang tidak dapat ditolak, karena masyarakat berada dalam era digitalisasi.

Komersialisasi bisnis menekan-kan pada tercapainya tujuan dari sebuah usaha yang dibangun, karena melibatkan sumber daya manusia hingga terpilihnya sumber informasi yang lebih terpercaya. Usaha untuk dapat membuat rencana strategis bisa dimulai dengan menyatakan tujuan yang hendak dicapai. Tujuan secara menyeluruh harus dapat diterjemahkan lebih spesifik.

Kunci keberhasilan sebuah bisnis tidak hanya terletak pada produk/jasa yang ditawarkan, tetapi juga pada sumber daya manusia yang memainkan peran kunci atas keberhasilan suatu usaha. Jika semua dapat berkolaborasi serta memahami secara jelas apa yang diharapkan serta keinginan untuk 
memunculkan dukungan dari semua pihak, tentunya akan dapat meraih tujuan dengan baik. Sumber daya bagi pengelola bisnis pada dasarnya tidak hanya sumber daya manusia saja, tetapi sumber daya kapital serta teknologi serta mekanisme kerja menjadi tulangpunggung bagi bekerjanya sebuah bisnis.

\section{Konsep Information Quality Dalam Ranah Bisnis Komunikasi}

Berbagai bentuk bisnis yang saat ini sedang dijalankan oleh masyarakat, akan tetap berkaitan dengan kegiatan pemasaran secara online. Dengan ketersediaan berbagai saluran yang akan memudahkan pebisnis dalam menjangkau khalayak, maka perlu optimalisasi secara berkelanjutan atas strategi yang dirancang dan dijalankan. Marketing melalui media online dijelaskan sebagai proses pemasaran dengan menggunakan teknologi komunikasi elektronik, khususnya internet (Priansa, 2017:305).

Informasi yang tersaji di website, merupakan satu kesatuan yang telah direncanakan secara matang. Sedangkan sistem informasi juga dipahami sebagai sebuah sistem yang meliputi sejumlah komponen penting dan memiliki keterikatan yang tinggi, baik itu manusia, komputer, prosedur kerja hingga keterlibatan teknologi informasi. Proses menjadikan data menjadi sebuah informasi yang utuh memang dimaksudkan untuk mencapai suatu tujuan, baik jangka pendek maupun jangka panjang.

Kebutuhan informasi menjadi bagian penting dalam upaya untuk mendukung proses kemudahan memperoleh informasi serta adanya fasilitas untuk menyebarluaskan informasi (Adi dkk, 2017:99). Saat ini masyarakat mengetahui berbagai macam saluran yang bisa digunakan untuk mendapatkan informasi, terutama yang berkaitan dengan pemanfaatan teknologi informasi. Selain itu, pemahaman kualitas informasi (information quality) semakin penting karena masyarakat memiliki kemampuan dalam memilih dan memilah informasi secara baik. Dari waktu ke waktu, proses ini terus berjalan, dan masyarakat senantiasa merasa senang apabila mendapatkan informasi dengan cepat dan mudah serta informasi yang tidak berbelitbelit.

Hal inilah yang patut diperhatikan oleh pengelola website, terutama yang bersinggungan langsung dengan dunia bisnis. Informasi dipahami sebagai sebuah pesan yang telah melalui proses konstruksi serta memiliki arti bagi pihak lain. Informasi erat kaitannya dengan sebuah nilai yang bisa benar atau juga salah serta memiliki nilai kebaruan yang menegaskan sesuatu bagi si penerima informasi. Sedangkan kualitas informasi (information quality) merupakan informasi yang sudah 
diproses oleh sebuah sistem sehingga memenuhi kebutuhan kualitas dari sebuah informasi.

Terkait dengan kompleksitas yang terkait dengan informasi, maka kualitas informasi disyaratkan sebagai sesuatu yang memenuhi kebutuhan masyarakat. Kualitas informasi juga bersifat multidimensi yang dikelompokkan kedalam 4 (empat) kategori yaitu intrinsik, kontekstual, representasi serta aksesibilitas atau keteraksesan (Wikipedia.org). Informasi dipahami sebagai data yang dianggap penting yang mampu memberikan pengetahuan dan berguna. Kualitas sebuah informasi memang harus akurat, relevan, tepat waktu dan nantinya terkait dengan manfaat serta biaya yang dikeluarkan untuk mendapatkan data yang diolah. Pengolahan ini pastinya melalui sebuah model yang akan menjadikan informasi sampai pada penerima dan akan bisa menerpa pada pemikiran si penerima, bahwa dengan adanya informasi tersebut akan dapat menentukan sebuah pengambilan keputusan serta tindakan, sehingga melahirkan informasi baru.

Dalam hal ini, yang patut diperhitungkan, bahwa nilai sebuah informasi ditentukan berdasarkan manfaat dan biaya yang harus dikeluarkan untuk mendapatkannya. Meskipun nilai tersebut tidak selalu mengacu kepada sesuatu yang sifatnya material saja. Memahaminya bahwa konsentrasi seseorang dalam mendapatkan informasi bersinggungan dengan energi yang harus dikeluarkan, bisa dari waktu, tenaga atau juga pikiran. Polapola yang terkait dengan hal ini mengacu pada biaya secara pribadi.

\section{METODE PENELITIAN}

Penelitian ini menggunakan metode kajian literatur dari berbagai buku dan jurnal. Kombinasi buku dan jurnal dijadikan sebagai sumber utama dengan menganalisis kasus atau fenomena sosial yang berkaitan dengan web dan teknologi komunikasi. Studi pustaka ini menggunakan kerangka berpikir sebagai acuan secara sistematis agar menghasilkan kajian yang lebih mutakhir.

\section{HASIL DAN PEMBAHASAN}

Perkembangan lingkungan makro yang terdiri dari teknologi, sosial dan ekonomi memiliki pengaruh terhadap pola pikir generasi yang akan lahir pada era-era yang akan datang (Suryani, 2013:250). Hal ini tentunya melihat bahwa setiap generasi akan memiliki perilaku yang berbeda. Generasi yang identik dengan maraknya penggunaan internet dalam kehidupan sehari-hari adalah generasi Y. Masingmasing generasi memiliki ciri khas yang melekat, sehingga memiliki kemampuan dalam mewujudkan ide-ide kedalam 
sebuah karya dan dapat diakui oleh masyarakat.

Transformasi digital ada di hadapan masyarakat, dan kecanggihan memiliki banyak manfaat, khususnya dalam dunia bisnis. Teknologi dihadirkan seakan memangkas waktu ketika dulu bisnis identik dengan kerja keras untuk mendapatkan pelanggan dalam jangka waktu yang lama. Saat ini teknologi ini hadir untuk dapat menghemat waktu, tenaga dan biaya. Rasa optimis untuk bisa mengoptimalkan rangkaian strategi bisnis terus diperdengarkan, karena bisnis harus bisa menyesuaikan dengan teknologi yang berkembang.

Utamanya dalam hal ini adalah bidang bisnis komunikasi. Tidak dapat dipungkiri bahwa perkembangan internet diikuti dengan perkembangan yang cepat di bidang telekomunikasi, akan dapat berdampak pada perilaku dari kalangan pebisnis. Masing-masing akan menawarkan atribut yang melengkapi strategi dalam berbisnis, dan akan semakin memposisikan produk serta jasanya di tengah-tengah masyarakat.

Kondisi ini tentu saja ketika saat ini masyarakat juga memiliki kemampuan dalam mengakses jaringan media sosial dan menjadikan media tersebut sebagai jembatan untuk membangun relasi dengan masyarakat lainnya. Penggunaan jejaring sosial, web site juga dari hari ke hari dapat dilihat arah peningkatan penggunaannya sehingga memiliki korelasi untuk membuka peluang bagi pemasar serta pihak-pihak yang akan mendukung proses pemasaran tersebut.

Pemasaran adalah proses sosial yang menempatkan individu atau juga kelompok hingga masyarakat luas untuk mendapatkan apa yang dibutuhkan. Keinginan ini bisa terwujud ketika satu pihak berupaya untuk menciptakan atau mempertukarkan produk atau jasa kepada yang lainnya. Jika terjadi transaksi, maka pada proses munculnya keinginan, ada produk yang dinggap dalam ranah pikiran hingga pengenalan, maka bisa dimungkinkan terjadi transaksi hingga ada keputusan pembelian.

Komunikasi pemasaran yang dijalankan beberapa periode yang lalu, melihat bahwa bentuk-bentuk komunikasi langsung menjadi medium yang efektif. Namun sekarang, dengan perkembangan masyarakat yang tidak bisa jauh dari teknologi, membuat satu peradapan baru yang lebih melirik kuasa teknologi dalam menghadirkan informasi yang cepat dan akurat serta menarik.

Optimalisasi penggunaan website untuk mendukung strategi pemasaran memang memberikan manfaat yang besar jika mampu memadupadankan akses media serta pengerahan konten secara tepat. 
Website memberikan akses yang kuat keseluruh dunia, sehingga dapat diakses secara cepat dan tepat. Sebagai pengunjung, tentunya masyarakat akan dapat memilih dan memilah informasi yang berguna dan bisa dimanfaatkan secara tepat, dan memangkas informasi yang tidak penting.

Meskipun penggunaan website semakin menggeliat, namun yang tidak bisa ditinggalkan adalah terbangunnya relasi sosial yang dikembangkan secara bersama-sama dalam kegiatan sosial ekonomi, serta memandang penting upaya untuk mendistribusikan ekonomi (Saudah, 2018:140). Relasi sosial yang terbentuk memberi sebuah penegasan bahwa kecanggihan dari sebuah teknologi, tetap belum mampu meninggalkan keinginan untuk berinteraksi secara personal maupun secara langsung. Pada tingkatan tertentu, di mana seseorang meyakini bahwa relasi yang terbentuk atas kontribusi dari media, dan mencoba menggeser pertemuan secara personal secara langsung. Sedangkan bagi beberapa pihak yang ada, teknologi juga bisa digunakan untuk saling berkomunikasi, misalnya melalui vitur video call yang dimiliki oleh handphone atau perangkat komputer. Dalam kurun waktu beberapa tahun ini, tumbuh nilainilai positif dari relasi yang dibangun dengan bantuan teknologi komunikasi
Maraknya teknologi komunikasi di tengah-tengah masyarakat menunjukkan suatu perubahan yang nyata di berbagai bidang bisnis (Saudah, 2018:104). Web site seakan memadukan publikasi cetak dan visual. Adapun tingkat kunjungan website juga dengan berbagai alasan yang ada misalnya dengan hosting yang digunakan, kemampuan teknis dari penyedia layanan internet serta beberapa hal lainnya.

Kehadiran internet bisa menjadi contoh yang bisa memperlihatkan bahwa teknologi internet ini adalah produk dari peradapan manusia, yang bisa menimbulkan budaya dan masyarakat dalam bentuk baru (Pratama, 2017:11). Hadirnya internet forum, jejaring sosial, blog dll adalah dampak dari munculnya teknologi yang mengubah peradapan dari masyarakat. Keterikatan di dunia maya menjadi sesuatu yang begitu menyenangkan hingga tumbuhnya polapola bisnis yang tidak pernah bisa lepas dari teknologi. Kemudahan seakan didapatkan ketika sentuhan teknologi ini semakin menguat.

Untuk meningkatkan aktivitas bisnis, tentunya juga merujuk pada upaya dari penyedia layanan untuk mengembangkan konten yang menarik. Benang merah dari adanya peningkatan layanan di bidang bisnis dengan adanya kunjungan dari masyarakat tentunya bermuara pada satu 
pemahaman bahwa ada sesuatu yang dipertukarkan.

Sistem pertukaran yang ada saat ini tidak hanya bersandar pada prinsip-prinsip pertukaran berlandaskan adanya kebutuhan yang dirasa dan adanya keinginan untuk melakukan pertukaran, tetapi tentunya menyangkut proses pertukaran yang dilakukan antara pihak-pihak yang berkepentingan (Rudito, dkk, 2007:viii).

Selama ini dipahami bahwa peluang pasar tidak selalu signifikan dengan penawaran barang dan jasa, sehingga mengharuskan semua pihak untuk melakukan inovasi di bidang bisnis. Perspektif komunikasi mencoba melihat hal ini sebagai sebuah peluang, karena dengan manajemen yang terstruktur, maka aktivitas bisnis dapat berjalan dengan baik.

Komunikasi bisnis di era digital menjadi hal yang sangat krusial, karena dengan kecepatan komunikasi yang ada, seakan menuntut terjadinya komunikasi yang efektif, meniadakan hambatan dengan berbagai aspek yang ada. Peran komunikasi bisnis di era digital ini menuntut pembuatan konten yang menarik sehingga mampu memancing interaksi di masyarakat dengan pengelola baik dalam lingkup kecil maupun besar.

Bentuk komunikasi online banyak terjadi, dan kecakapan dalam mengolah konten lebih dominan dari pada kecakapan secara tatap muka langsung yang menekankan pada kemampuan berkomunikasi yang baik.

Jika ditekankan pada manajemen desain yang nantinya diharapkan dapat meningkatkan aktivitas bisnis, maka ada beberapa hal yang harus terus dioptimalkan, salah satunya adalah responsif. Sejalan dengan kecepatan teknologi menghampiri masyarakat, tentunya user tidak mau berlama-lama menunggu jawaban jika memulai untuk berkomunikasi dengan pengelola. Satu hal yang paling mendasar kemampuan berkomunikasi di dunia maya adalah kompetensi yang mutlak harus dimiliki oleh pebisnis.

Dengan upaya untuk mengenali setiap users yang merespon informasi yang dilayangkan, adalah upaya untuk dapat menjangkau hingga nantinya keputusan pembelian dapat terlaksana dengan baik. Memanfaatkan website untuk memasarkan produk/jasa adalah merupakan konsep pemasaran yang akan mencuri perhatian di sebuah keramaian dunia maya. Tentu saja harus ada pembeda dibandingkan yang lain, serta dilakukan secara berkelanjutan atau terus menerus. Hal ini semakin memperkuat posisi produk di pasar.

Bagaimanapun juga manajemen desain pada media komunikasi website adalah langkah yang ditempuh untuk bisa lebih kompetitif dengan melakukan digitalisasi bisnis. Era digital sudah 
melebur dalam kehidupan masyarakat, sehingga banyak peluang serta tantangan bisnis yang dihadapi. Kendatipun kebebasan dan kecepatan informasi telah ada, tetap harus mencoba merangkai sebuah manajemen yang professional, karena peluang adalah merupakan good news bagi pengelola bisnis.

Manajemen kinerja haruslah menjadi dasar penopang yang kuat bagi terselenggaranya bisnis di era digital. Bacal dalam Wibowo (2014:7) menjelaskan bahwa manajemen kinerja adalah proses komunikasi yang dilakukan secara terus menerus dalam kemitraan yang melibatkan karyawan hingga atasan langsung. Proses komunikasi sendiri dalam hal ini mengarah kepada kegiatan yang ditujukan untuk membangun harapan yang jelas serta tumbuhnya pemahaman tentang pekerjaan yang dilakukan. Manajemen kinerja adalah proses yang berkelanjutan, sehingga menemukan strategi yang lebih sistemik dengan menanfaatkan kehadiran teknologi. Perencanaan strategi harus dilakukan sejak awal untuk dapat memformulasikan hingga mengevaluasi langkah kerja yang diambil.

Teknologi yang hadir menuntut pebisnis untuk lebih adaptif terhadap berbagai konsekwensi yang lahir. Hal tersebut tentunya kembali kepada sumber daya manusia yang professional dalam mengelola teknologi yang dipilih. Dengan melihat keinginan masyarakat yang setiap saat berubah, menuntut sesuatu yang baru dan cepat tentunya dipahami sebagai kompleksitas yang harus bisa dijawab dan diselesaikan oleh pengelola bisnis.

Tantangan yang ada seakan menuntut pebisnis untuk berinovasi dalam menciptakan produk/jasa untuk menghasilkan sesuatu yang memiliki keunikan namun tetap bermanfaat bagi masyarakat. Keuntungan yang lebih maksimal kedepannya harus bisa diperhitungkan sedemikian rupa karena telah mampu mengintegrasikan teknologi dengan sumber daya manusia tanpa ada batasan ruang dan waktu.

Satu hal yang juga harus dipahami adalah kolaborasi yang saat ini banyak dilakukan oleh pebisnis. Bukan persaingan yang dominan muncul, tetapi kemampuan dalam menangkap peluang. Kemampuan untuk membujuk juga harus muncul, karena persuasi adalah bagian yang sangat penting dalam semua bisnis, dan penjualan online adalah lebih menantang dari pada bentuk persuasi lainnya (Guffey dkk, 2006:56). Untuk itu diperlukan teknik khusus dalam mencapai tujuan.

\section{PENUTUP}

\section{Simpulan Dan Saran}

Optimalisasi manajemen desain yang mengakar kuat dalam aktivitas bisnis memberikan ruang gerak bagi sumber daya 
manusia untuk menghasilkan karya yang bernilai tinggi karena melibatkan strategi serta mengembangkan kreativitas dan mengelola sebuah sistem yang efektif dan efisien. Manajemen desain pada media komunikasi website merupakan kegiatan yang komprehensif karena menyelaraskan strategi desain dan kepentingan organisasi untuk meninkatkan aktivitas bisnis. Hal ini saja untuk memunculkan metode baru serta menemukan solusi yang atas permintaan pasar, karena memastikan kualitas desain hingga konsistensi desain. Kesemuanya itu tidak hanya meletakkan teknologi sebagai pijakan bisnis, tetapi juga adanya kemampuan dari sumber daya manusia yang merancang sebuah konten hingga mengevaluasi secara berkesinambungan.

\section{Daftar Pustaka}

Adi, D., \& Pandalu, R. (2017). Efektivitas Pelayanan Informasi Internal Kampus Melalui Pemanfaatan Media Interaktif Berbasis Artom (Studi Fenomenologi Pada Mahasiswa FISIP Universitas Merdeka Malang). Seminar Nasional Sistem Informasi (SENASIF), 1(1), $91 \quad-\quad 100$. Retrieved from https://jurnalfti. unmer.ac.id/index.php/senasif/artic le/view/19.

Guffey, mary Ellen. Rhodes, Kathleen. Rogin, Patricia. 2006. Komunikasi Bisnis: Proses \& Produk. Jakarta. Salemba Empat.

Pratama, Bayu Indra. 2017. Etnografi Dunia Maya Internet. Malang. UB Press
Rudito, Bambang. Famiola, Melia. 2007. Etika Bisnis dan Tanggung Jawab Sosial Perusahaan di Indonesia. Bandung. Rekayasa Sains.

Suryani, tatik. 2013. Perilaku Konsumen di Era Internet. Implikasinya pada strategfi Pemasaran. Yogjakarta. Graha Ilmu.

Saudah. 2018. Kontekstasi Pedagang Pasar Tradisional dalam mempertahankan Relasi Sosial dan Komunikasi.

https://ejournal.unida.gontor.ac.id/i ndex.php/ettisal/article/view/1931/ pdf_21.

Saudah. 2018. Dampak Perkembangan Teknologi Komunikasi Seluler Terhadap Perilaku Adaptif Pedagang Pasar Tradisional. https://www.researchgate.net/publicati on/326930081_DAMPAK_PERKEM BANGAN_TEKNOLOGI_KOMUNI KASI_SELULER_TERHADAP_PER ILAKU_ADAPTIF_PEDAGANG_P ASAR_TRADISIONAL?enrichId=rgr eq6f0df5bbb29e44600d016168d6bf629c

XXX\&enrichSource $=$ Y292ZXJQYW dlOzMyNjkzMDA4MTtBUzo2NTc5 Njk2OTE3NzQ5NzhAMTUzMzg4M zYwNzgyMg\%3D\%3D\&el=1_x_3\&_ esc=publicationCoverPdf

Triono, Maulid Agung. Setiyaningsih, Lian Agustina. 2017. Desain Disonansi Kognitif Sebagai Faktor Anteseden Untuk Penguatan Kualitas Informasi Pada Website. https://scholar.google.co.id/schola $r ?$ oi $=$ bibs\&cluster $=176392152051$ $15003443 \& b t n I=1 \& h l=e n$

Wikipedia.org. Kualitas Informasi. https://id.wikipedia.org > wiki >Kualitas_informasi 